\title{
Microbial protein and peptide metabolism in rumen fluid from faunated and ciliate-free sheep
}

\author{
BY R. J. WALLACE, G. A. BRODERICK* \\ AND MARGARET L. BRAMMALL \\ Rowett Research Institute, Bucksburn, Aberdeen AB2 9SB
}

(Received 29 September 1986 - Accepted 20 January 1987)

1. Protease and deaminase activities and the metabolism of peptides were measured in rumen fluid from ciliatefree sheep and from sheep with a limited population of small entodinia. The same measurements were repeated following inoculation of the latter group with a more typical mixed ciliate population.

2. Protease and dialanine uptake activities of mixed rumen micro-organisms were not significantly influenced by protozoa. Trialanine uptake, leucine aminopeptidase (EC 3.4.11.1), deaminase and trypsin-like protease activities were $70,107,73$ and $91 \%$ higher with the limited population, and $72,58,64$ and $55 \%$ higher when mixed protozoa were present, indicating a major role for the protozoa in these activities.

Defaunation of the rumen of cattle and sheep receiving diets low in protein improves growth rate (Bird \& Leng, 1978) and wool growth in sheep (Bird et al. 1979). Improved performance was not observed with diets higher in protein (Eadie \& Gill, 1971; Williams \& Dinusson, 1973). Indeed, young lambs fed on high-protein diets achieved higher growth rates (Abou Akkada \& el-Shazly, 1964) and nitrogen retention was increased (Abou Akkada \& el-Shazly, 1965) in the presence of rumen protozoa. The implication of these results is that defaunation causes an increased flow of protein from the rumen, which only becomes beneficial when the host animal is protein-deficient. The increase in non-ammonia$\mathrm{N}$ flowing to the duodenum may not even be statistically significant (Rowe et al. 1985), which is a little surprising in view of the improved microbial growth yield and decreased bacterial protein turnover that occurs when the predatory effect of protozoa on bacteria is eliminated (Demeyer \& Van Nevel, 1979; Leng \& Nolan, 1984; Rowe et al. 1985; Wallace \& McPherson, 1987).

Several species of protozoa and mixed protozoal populations from rumen fluid have been found to hydrolyse exogenous, non-bacterial protein, and to metabolize peptides and amino acids (Coleman, 1980; Williams, 1986). However, little is known of what is the relative impact of protozoa on the various steps in the conversion of food protein to ammonia in the rumen. The work described in the present paper attempts to answer this ecological question by comparing several metabolic activities of rumen fluid from faunated and ciliate-free sheep.

\section{MATERIALS AND METHODS}

Experimental animals, diet and sampling procedure

Five faunated and five ciliate-free Suffolk x Finn Dorset sheep, aged 12-20 months and weighing $40-55 \mathrm{~kg}$, were fed twice daily at 08.00 and 16.00 hours. The ciliate-free sheep had been housed in isolation pens from birth. The five faunated animals were originally isolated, but had become accidentally contaminated with small entodinia at least 7 months before the experiments began. Each meal consisted of $250 \mathrm{~g}$ dried grass and $125 \mathrm{~g}$ concentrate consisting of $(\mathrm{g} / \mathrm{kg})$ : maize 571 , oats 142 , wheat bran 142 , linseed cake 71 , white fish meal 71, vitamin supplement 4. Samples of rumen fluid were removed $2-4 \mathrm{~h}$ after the

* Present address: US Dairy Forage Research Center, University of Wisconsin, Madison, WI 53706, USA. 
morning feed, by stomach tube from the faunated sheep and via the rumen cannula fitted to the ciliate-free animals. Any of the former samples that were visibly contaminated with saliva were rejected. The rumen fluid was maintained at $39^{\circ}$ for about $5 \mathrm{~min}$, until it was strained through four layers of muslin. Assays were then done immediately.

Two sets of samples were taken on separate days from both groups of animals. The faunated group was then inoculated orally with $50 \mathrm{ml}$ rumen fluid from a sheep with a type A ciliate population (Eadie, 1962). At 3 weeks the sampling of both groups was repeated.

\section{Measurement of microbial metabolic activities}

Proteolytic activity was measured by the hydrolysis of ${ }^{14} \mathrm{C}$-labelled casein (Wallace, 1983). Hydrolysis of benzoyl-L-arginine $p$-nitroanilide (BAPNA) and L-leucine $p$-nitroanilide (LNA) was measured in an assay mixture containing $0.6 \mathrm{ml}$ strained rumen fluid (SRF), $0.2 \mathrm{ml} 25 \mathrm{~mm}$-potassium phosphate, $\mathrm{pH} 7.0$ (boiled and bubbled with carbon dioxide), and $0.2 \mathrm{ml} p$-nitroanilide substrate dissolved in $25 \mathrm{~mm}$-potassium phosphate containing $100 \mathrm{ml}$ ethanol/1. Following a $10 \mathrm{~min}$ incubation at $39^{\circ}, 0.25 \mathrm{ml}$ trichloroacetic acid $(250 \mathrm{~g} / \mathrm{l}$; TCA) was added to stop the reaction. The $p$-nitroaniline released was determined colorimetrically following diazotization of the supernatant fluid (12000 g, $3 \mathrm{~min}$ ) (Appel, 1974). Amino acid deamination was measured in a similar assay mixture, except that $5 \mathrm{mg}$ casein acid-hydrolysate (Oxoid) $/ \mathrm{ml}$ replaced the $p$-nitroanilide solution. TCA was added after $2 \mathrm{~h}$ at $39^{\circ}$ and ammonia in the supernatant fluid was determined by the phenol-hypochlorite method (Weatherburn, 1967). Di- and tripeptide uptake was estimated using di-L-alanine $\left(\right.$ ala $\left._{2}\right)$ and tri-L-alanine $\left(\right.$ ala $\left._{3}\right)$ as substrates in a mixture which contained $0.8 \mathrm{ml} \mathrm{SRF} / \mathrm{ml}$, with final concentrations of $25 \mathrm{~mm}$-potassium phosphate, $0.25 \mathrm{~mm}$ peptide and $\mathrm{pH} 7.0$. This mixture was incubated at $39^{\circ}$ for $20 \mathrm{~min}$, then centrifuged at $12000 \mathrm{~g}$ for $2 \mathrm{~min}$ and the supernatant fluid was held on ice. Within $1 \mathrm{~h}$, remaining peptide was assayed by a modification of the fluorimetric method of Perrett et al. (1975). Supernatant fluid (75 $\mu \mathrm{l})$ was added to $2.25 \mathrm{ml} 0.20 \mathrm{M}$-sodium citrate buffer, $\mathrm{pH} 6.2$. Just before fluorescence assay, $0.75 \mathrm{ml}$ freshly prepared fluorescamine solution $(0.28 \mathrm{mg} / \mathrm{ml}$ acetone $)$ was added while the mixture was vortexed. The mixture was vortexed for a further 3-4 s and the fluorescence was measured using excitation at $390 \mathrm{~nm}$ and emission at $485 \mathrm{~nm}$. Response was measured while the fluorescence was stable (between 2 and $20 \mathrm{~min}$ after fluorescamine addition). The protein content of SRF was determined by precipitating protein in TCA $(50 \mathrm{~g} / 1)$, centrifuging $(48000 \mathrm{~g}, 10 \mathrm{~min})$, and measuring the protein content of the pellet using the Folin reagent (Herbert et al. 1971).

\section{Protozoal counts}

Samples of SRF were preserved by the addition of an equal volume of formaldehyde ( $40 \mathrm{~g} / \mathrm{l}$ ). Large protozoa ( $>100 \mu \mathrm{m}$ diameter) were counted by direct light microscopy, by scanning $8 \times 5 \mu \mathrm{l}$ portions under low power $(\times 100)$. Small $(<100 \mu \mathrm{m})$ protozoa were counted at higher magnification $(\times 400)$, using a haemocytometer, and were the means of $16 \times 0 \cdot 1 \mu 1$ volumes. Portions were removed while the preserved sample was stirred using a magnetic stirrer to maintain protozoa in homogeneous suspension. The pipette tip was enlarged to $1 \mathrm{~mm}$ diameter to accommodate the largest protozoa. Counts are expressed as means and their standard deviations.

\section{Statistical analysis}

Differences between ciliate-free sheep and sheep with small entodinia were assessed in the first set of samples using an unpaired $t$ test. The effect of inoculating with large protozoa was assessed by comparing the differences between faunated sheep and the second set of ciliatefree samples with the same differences in the first set of samples, using an unpaired $t$ test. Because of the relatively small sample size, normality and equality of variance in the two 
groups was examined. There was no evidence, from histograms and normal plots, that any of the variables was not normally distributed. In the cases where there was evidence of a difference in the variance between the two groups, the degrees of freedom were estimated using the formula

$$
\frac{\left[\left(s_{1}{ }^{2} / n_{1}\right)+\left(s_{2}{ }^{2} / n_{2}\right)\right]^{2}}{\frac{\left(s_{1}{ }^{2} / n_{1}\right)^{2}}{n_{1}-1}+\frac{\left(s_{2}{ }^{2} / n_{2}\right)^{2}}{n_{2}-1}}
$$

where $s_{1}{ }^{2}$ and $s_{2}^{2}$ are the sample variances and $n_{1}$ and $n_{2}$ are the numbers of observations in groups 1 and 2 respectively.

\section{RESULTS AND DISCUSSION \\ Development of protozoal populations}

Ciliate protozoa were absent from the sheep that had been isolated from birth. The second, faunated, group was colonized by a limited population of small entodinia at the beginning of the experiment, with a count of 5.2 (SD 3.6) $\times 10^{5} / \mathrm{ml} \mathrm{SRF}$. The faunated sheep were then inoculated with a mixed type A population including Polyplastron, holotrichs and large ( $>100 \mu \mathrm{m}$ ) entodinia. After 3 weeks the population of small entodinia had fallen to $3 \cdot 3$ (SD $1.5) \times 10^{5} / \mathrm{ml}$, with $7.9(\mathrm{SD} 5.3) \times 10^{3}$ large mixed protozoa $/ \mathrm{ml}$ present. The average protein content of SRF was highest in ciliate-free sheep and lowest in rumens with a mixed protozoal population (Table 1).

Samples of rumen fluid from the two groups were removed in different ways. The ciliatefree sheep were cannulated, so samples were taken by this route. Stomach tube samples were taken from faunated sheep. Thus potential differences between the two groups were the method of sampling, and the different sites from which samples were probably taken. The main effect of sampling by stomach tube is usually to contaminate the sample with saliva. This was kept to a minimum throughout these experiments by discarding samples with visible salivary contamination. In any case, the enzymic activities reported here are negligible in saliva (R. J. Wallace, unpublished results). Thus the main effect would be one of dilution, affecting $\mathrm{NH}_{3}$ and protein content. Comparisons of enzyme activities expressed per unit of protein are therefore still likely to be valid.

\section{Proteolytic activity}

The protease activity of SRF, expressed per $\mathrm{ml}$, was slightly lower in faunated sheep than in ciliate-free animals (Table 1). However, this was apparently the result of a fall in the protein content of SRF, because the activities per $\mathrm{mg}$ protein were not significantly different (Table 1). Introduction of large protozoa to sheep with an existing population of small entodinia had no significant effect.

In contrast, BAPNA, a synthetic substrate for enzymes of trypsin-like specificity, was hydrolysed significantly more rapidly in animals with the limited population. Here, the introduction of large protozoa abolished the difference between faunated and ciliate-free SRF, expressed per $\mathrm{ml}$ SRF. There was still a trend for a higher activity per $\mathrm{mg}$ protein, but this was not statistically significant because of a high variance.

The finding that protozoa have little effect on the caseinolytic activity of rumen contents is in accord with the results of Brock et al. (1982), who found that the activity of mixed protozoa against azocasein was only one-tenth that of rumen bacteria. Also, Nugent \& Mangan (1981) observed that labelled amino acids from fraction I protein were incorporated first by bacteria, before being transferred to protozoa as a result of predation. The protozoa may have a much greater ecological role in the breakdown of bacterial protein, and possibly other proteins in a small particulate form, rather than in the breakdown of soluble proteins (Naga \& el-Shazly, 1968; Coleman, 1980; Wallace \& McPherson, 1987). 
R. J. WALLACE AND OTHERS

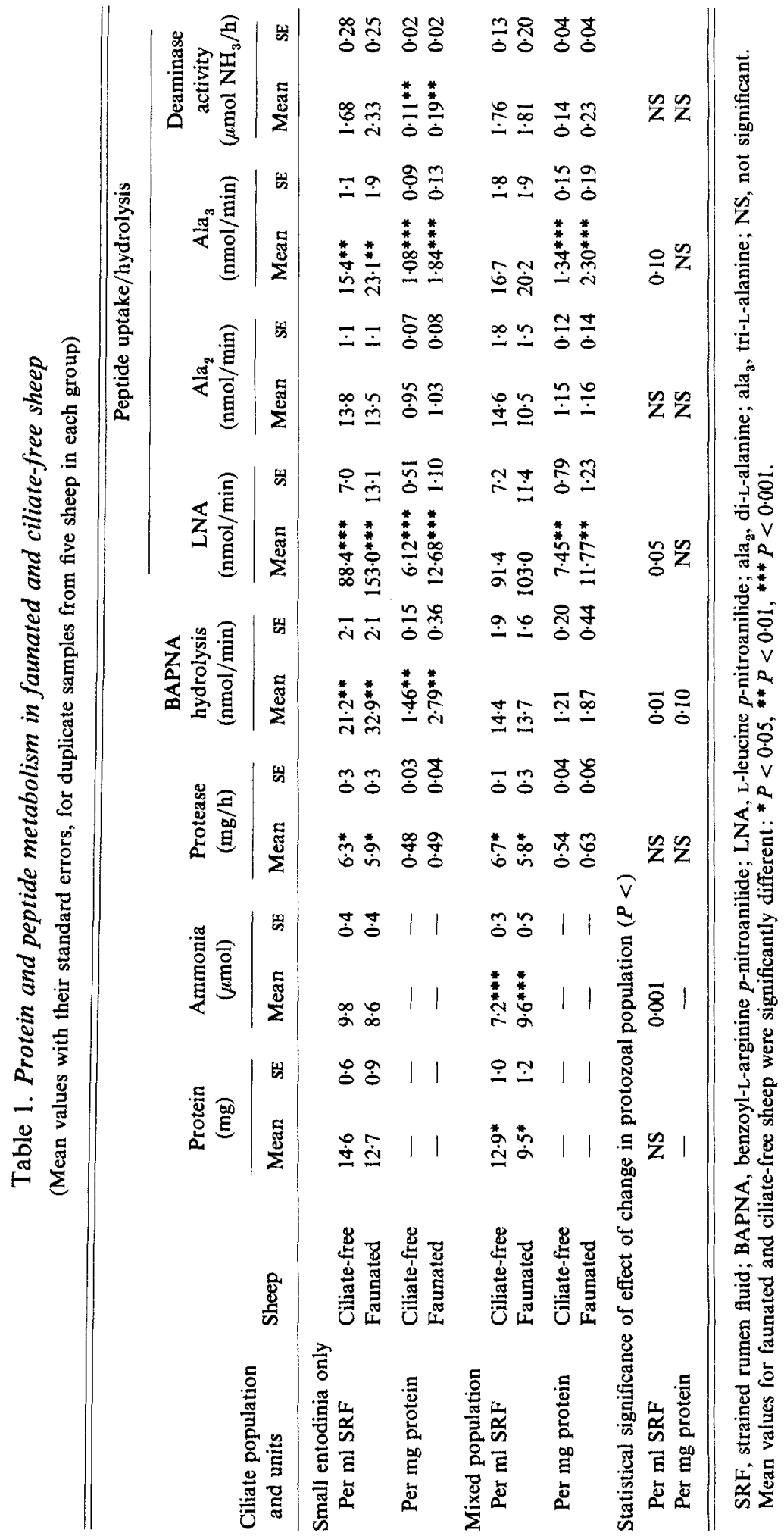


Forsberg et al. (1984) found that the BAPNA-hydrolyzing activity of mixed protozoa was 1.3 times that of bacteria per unit protein, a result that is supported here by the increased specific activity of the mixed population. Small entodinia seemed to have the highest BAPNA-hydrolyzing activity, as the limited population was most active (Table 1). Entodinium caudatum has previously been shown to have an activity with this specificity (Abou Akkada \& Howard, 1962). Nevertheless, the different patterns of ${ }^{14} \mathrm{C}$-labelled casein and BAPNA hydrolysis in these samples suggest that protozoal trypsin-like enzymes are of relatively minor importance in the breakdown of exogenous soluble protein.

\section{Peptide metabolism}

There is some published information on the metabolism of peptides by rumen bacteria (Cotta \& Hespell, 1986), but relatively little is known about this aspect of protozoal metabolism (Coleman, 1980; Williams, 1986). Mixed protozoa do have a high leucine aminopeptidase activity (Forsberg et al. 1984), and Entodinium caudatum produces a peptidase active against a range of dipeptides and glycylglycylglycine (Abou Akkada \& Howard, 1962). However, Wright's (1967) experiments on the fate of ${ }^{14} \mathrm{C}$-labelled Chlorella peptides did not distinguish between protozoal and bacterial activities. Only incorporation into bacterial protein, particularly of large peptides, was demonstrated. Furthermore, the minor extent to which ${ }^{14} \mathrm{C}$ was incorporated by protozoa during the early hydrolysis of labelled fraction I protein (Nugent \& Mangan, 1981) was probably due to a low proteolytic rather than peptidolytic activity.

In the present experiments (Table 1), higher leucine aminopeptidase (EC 3.4.11.1) activities in faunated sheep were consistent with the findings of Forsberg et al. (1984). The activity appears to be associated mainly with small entodinia since the specific activity was not significantly affected by the inoculation of larger protozoa. The fall in activity per $\mathrm{ml}$ SRF on addition of large protozoa was due to the fall in the protein content of SRF. $\mathrm{Ala}_{3}$ uptake followed a similar pattern, and is probably also a significant activity of small entodinia. $\mathrm{Ala}_{2}$ uptake was, in contrast, the same in cilate-free and faunated animals indicating that rumen dipeptidase activity is primarily of bacterial origin. It should be noted here that the experimental measurement of ala $_{2}$ and ala $_{3}$ metabolism was their disappearance from the extracellular medium. Hence, both intracellular accumulation and hydrolysis could have been responsible, and the general term 'uptake' is used.

\section{Amino acid catabolism}

The influence of faunation in increasing deaminase activity only reached significance $(P<0.01)$ when comparing ciliate-free sheep and those with small entodinia and when the results were expressed per $\mathrm{mg}$ protein (Table 1). However, the difference approached significance $(P<0 \cdot 10)$ in the same samples when deaminase activity was expressed per $\mathrm{ml}$ SRF, and when the activities per $\mathrm{mg}$ protein in ciliate-free and faunated SRF were compared after large species were introduced. Large protozoa did not cause a significantly different specific activity from that observed with small entodinia alone. Thus protozoa, particularly small entodinia, tended to cause an increase in the rate of deamination of amino acids in SRF.

Deamination of amino acids has previously been observed in many mixed populations and individual protozoal species (Coleman, 1980; Williams, 1986), and Hino \& Russell (1985) found that the specific activity of protozoa was three times higher than that of rumen bacteria. The present observations therefore confirm the importance of protozoa in deamination of amino acids by the mixed rumen population.

An increased rumen $\mathrm{NH}_{3}$ concentration is often associated with the presence of protozoa (Coleman, 1980), and is usually presumed to arise from the increased breakdown of 
bacterial protein (Hobson \& Wallace, 1982). In the present experiments, the influence of protozoa on $\mathrm{NH}_{3}$ concentration depended on the species present. Small entodinia, despite their generally stimulatory influence on peptide and amino acid metabolism, actually gave a lower rumen $\mathrm{NH}_{3}$ concentration in faunated sheep (Table 1). When large protozoa were introduced, the situation was reversed and the $\mathrm{NH}_{3}$ concentration in faunated SRF was higher than that in the parallel set of ciliate-free samples. However, all of these effects were relatively minor in comparison with the near-doubling in $\mathrm{NH}_{3}$ concentration reported by Eadie \& Gill (1971). This may reflect the relatively small numbers of protozoa present.

\section{Microbiological considerations}

In some studies of faunated and ciliate-free ruminants, chemicals have been used to eliminate protozoa from already faunated animals. This method has the disadvantage that the chemical may affect the bacteria as well (Eadie \& Shand, 1981). Conclusions regarding the role of protozoa, rather than the effect of the defaunating agent, are therefore difficult to make. The methods used in the present paper, where protozoa were excluded by isolation of the animals instead of the addition of chemicals, will clearly not cause toxicity to bacteria and therefore may be better, but they still do not preclude population changes in the bacterial flora. For example, in the present experiments, simple microscopic examination indicated an increased proliferation of oval-shaped organisms in ciliate-free lambs. No account was taken of these changes in the background flora because of the difficulty in removing large bacteria from protozoal preparations.

Another drawback of the present experiments is that the microbial population associated with particulate material, which may contribute up to $70 \%$ of microbial ATP in rumen contents (Forsberg \& Lam, 1977), was removed by straining the samples before measurements were made. The solids-associated population could be different from the microbial population of SRF and might have different activities. Nevertheless, measurements and protozoal counts made with SRF still indicate the likely role of protozoa in whole rumen contents. The decrease in the protein content of SRF is, for example, consistent with the effect of protozoa in decreasing the net microbial growth yield (Demeyer \& Van Nevel, 1979).

\section{CONCLUSIONS}

The results presented here suggest that the ciliate protozoa, particularly small entodinia, were more active in some peptidase and deaminase activities than rumen bacteria. Their contribution to protease and dipeptidase activities of rumen fluid was, in contrast, no more than that of the bacteria. Thus removal of protozoa as a nutritional strategy may have a major impact on some aspects of rumen $\mathrm{N}$ metabolism, but very little on others. The effect on the overall $\mathrm{N}$ economy of the animal will therefore depend on the relative importance of each of the hydrolytic steps on the overall flux of $\mathrm{N}$ to ammonia.

The authors thank Dr J. M. Eadie and Mr W. Shand for the use of their sheep, and for their advice and help in these experiments. The statistical analysis done by Mrs H. Vint is gratefully acknowledged.

\section{REFERENCES}

Abou Akkada, A. R. \& el-Shazly, K. (1964). Applied Microbiology 12, 384-390.

Abou Akkada, A. R. \& el-Shazly, K. (1965). Journal of Agricultural Science, Cambridge 64, 251-255.

Abou Akkada, A. R. \& Howard, B. H. (1962). Biochemical Journal 82, 313-320.

Appel, W. (1974). In Methods of Enzymatic Analysis, 2nd ed., pp. 949-978 [H. U. Bergmeyer, editor]. London: Academic Press.

Bird, S. H., Hill, M. K. \& Leng, R. A. (1979). British Journal of Nutrition 42, 81-87. 
Bird, S. H. \& Leng, R. A. (1978). British Journal of Nutrition 40, 163-167.

Brock, F. M., Forsberg, C. W. \& Buchanan-Smith, J. G. (1982). Applied and Environmental Microbiology 44, $561-569$.

Coleman, G. S. (1980). Advances in Parasitology 18, 121-173.

Cotta, M. A. \& Hespell, R. B. (1986). In Control of Digestion and Metabolism in Ruminants, pp. 122-136 [L. P. Milligan, W. L. Grovum and A. Dobson, editors]. Englewood Cliffs, New Jersey: Prentice-Hall.

Demeyer, D. \& Van Nevel, C. J. (1979). British Journal of Nutrition 42, 515-524.

Eadie, J. M. (1962). Journal of General Microbiology 29, 579-588.

Eadie, J. M. \& Gill, J. C. (1971). British Journal of Nutrition 26, 155-167.

Eadie, J. M. \& Shand, W. J. (1981). Proceedings of the Nutrition Society 40, 113A.

Forsberg, C. W. \& Lam, K. (1977). Applied and Environmental Microbiology 33, 528-537.

Forsberg, C. W., Lovelock, L. K. A., Krumholz, L. \& Buchanan-Smith, J. G. (1984). Applied and Environmental Microbiology 47, 101-110.

Herbert, D., Phipps, P. J. \& Strange, R. E. (1971). In Methods in Microbiology, vol. 5B, pp. 209-344 [J. R. Norris and D. W. Ribbons, editors]. London: Academic Press.

Hino, T. \& Russell, J. B. (1985). Applied and Environmental Microbiology 50, 1368-1374.

Hobson, P. N. \& Wallace, R. J. (1982). Critical Reviews in Microbiology 9, 165-225.

Leng, R. A. \& Nolan, J. V. (1984). Journal of Dairy Science 67, 1072-1089.

Naga, M. A. \& el-Shazly, K. (1968). Journal of General Microbiology 53, 305-315.

Nugent, J. H. A. \& Mangan, J. L. (1981). British Journal of Nutrition 46, 39-58.

Perrett, D., Webb, J. P. W., Silk, D. B. A. \& Clark, M. L. (1975). Analytical Biochemistry 68, 161-166.

Rowe, J. B., Davies, A. \& Broome, A. W. J. (1985). British Journal of Nutrition 54, 105-119.

Wallace, R. J. (1983). British Journal of Nutrition 50, 345-355.

Wallace, R. J. \& McPherson, C. A. (1987). British Journal of Nutrition 58 (In the Press).

Weatherburn, M. W. (1967). Analytical Chemistry 39, 971-974.

Williams, A. G. (1986). Microbiological Reviews 50, $25-49$.

Williams, P. P. \& Dinusson, W. E. (1973). Journal of Animal Science 36, 588-591.

Wright, D. E. (1967). Applied Microbiology 15, 547-550. 